13.92であった。

4. 上顎第 1 大曰菌前方咬合小面矢状断面傾斜角の最大 徝は $37^{\circ}$, 最小偲は $10^{\circ}$ で, 平均值と標準偏差は $20.7 \pm$ $7.81^{\circ}$ であった。

5. 矢状切荬路傾斜角之上䫇中切歯前方咬合小面天状断 面傾斜角との相関係数は 0.78 であり, 高度に有意の相 関関係が認められた。

6. 欠状顆路傾斜角之上顎中切菌前力咬合小面矢状断面 傾斜角との相関係数は-0.49であり，有意の相関関係 が認められた。

今後咬合様式による分類を行い，咬合様式別に顆路之 歯牙路との関係について検討する尒定である.

\section{2. 下顎前歯の植立状態について}

\section{佐藤 清高 (九歯大・ 1 補緅)}

上顎前歯部は審美性と密接な関係があるため，柬牙の 形態抢よび植立状態について，涏来多くの研究報告があ る.ところが下顎前畨は, 談話時, 微笑時に見えるにも かかわらず，その形態および植立状態に関してはほとん ど検討されていない，そこで植立状態に扔ける下顎前柬 の正面形態について計测を行った。

本研究は下顎前歯部正面形態を検討するのが目的であ るので，模型上で直接計測する方法よりも多くのデータ が得られるトレース法により，20才代罗性について計測 した。

結果の概要は以下のとおりである。

1. 米冠長径の西均と標準偏差は 3 で $9.5 \pm 1.21 \mathrm{~mm}$,

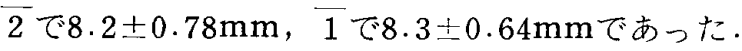

2. 歯冠幅徍は 3 で $5.7 \pm 0.48 \mathrm{~mm}, \overline{2}$ で $5.7 \pm 0.50 \mathrm{~mm}$, テで5.5土0.36mmであった。

3. 正中線から切端点までの距離は 3 で $14.0 \pm 1.15$ $\mathrm{mm}, \overline{2}$ で $8.3 \pm 0.69 \mathrm{~mm}, \overline{1}$ で $2.7 \pm 2.30 \mathrm{~mm}$ であっ た。

4. 正中線から歯肉点までの距離は $\overline{3}$ で $17.0 \pm 0.47$ $\mathrm{mm}, \overline{2}$ で $11.3 \pm 0.45 \mathrm{~mm}, \overline{1}$ で $5.5 \pm 0.35 \mathrm{~mm}$ であ $っ た$.

5. 歯冠軸傾斜角は 3 で $7.5 \pm 5.43^{\circ}, \overline{2}$ で $1.2 \pm 4.63^{\circ}$,

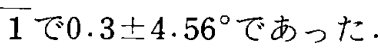

6. 歯冠側鼓形空陌は $\overline{32}$ 間で $4.2 \pm 1.09 \mathrm{~mm}^{2}, \overline{21}$ 間 で $3.3 \pm 0.78 \mathrm{~mm}^{2}, \overline{1 \mid 1}$ 間で $2.9 \pm 0.93 \mathrm{~mm}^{2}$ であっ た.

7. 雬頸側鼓形空陌は 32 間で $0.5 \div 0.41 \mathrm{~mm}^{2}, \overline{21}$ 間
で $0.1 \pm 0.09 \mathrm{~mm}^{2}, \overline{1 / 1}$ 間で $0.1 \pm 0.05 \mathrm{~mm}^{2}$ であっ た.

今回は個性正常咬合在有する20才代男性20名の下顎前 雨部の植立状態の正再観について計測を行った．今後は 30才代，40才代，50才代の被検者を対象にして同様に計 測を行い，比較検討するつもりである。

\section{3. 舌房の形態的特徵に関する研究 第 2 報 総義蔝患者 について}

\section{加来 哲 (九蒾大・ 1 補綴)}

天然歯は舌圧，煩，口唇圧の拮抗する笳圧中立率に萌 出し，柬列が完成するといわれている．また総義歯の人 工歯排列にあたっては，筋压中立帯内に排列して筋圧に より脱離されないで安定した義歯を作製する，いわゆる フランジ・テクニックが紹介されている。そてで, 舌砫 が有歯顎者の天然歯列弓と無歯䫟者の人工歯列弓に与え る影響について検討するために，有斗顎者の舌房とフラ ンジ・テクニックにより採得された涠歯顎者の筋圧中立 带の舌房の形態を比較したところ，以下のような結果を 得た。

今回正常有䨑頍者の天然雪列引と, フランジテクニッ クにより採得された無歯顎者の筋圧中立带を比較したと ころ,以下のような結果を得た。

1. 舌房幅径の平均值と柾準偏差は, 有歯顎者で 44.9

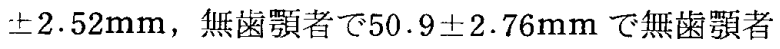
の方が大であった。

2. 舌房長径は, 有歯顎者で $43.0 \pm 3.42 \mathrm{~mm}$, 無歯顎 者で $41.2 \pm 3.77 \mathrm{~mm}$ であったが，兩者の平均值の間 に有意差はなかった。

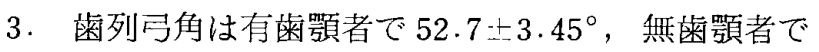
$64.4 \pm 4.07^{\circ}$ で，無柬䋶者では巨歯部で拉大された 速列当となっていた。

4. 舌房面積は有歯顎者で $1,420 \pm 1,17.2 \mathrm{~mm}^{2}$, 無

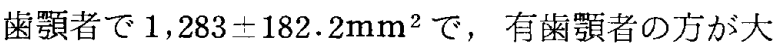
であった。

有歯顎では米牙が歯慒㝵に堅固に植立しているのに対 し, 無歯頢者で得られた筋王中立萦はソフトプレートワ ックスにより機能的に形成されたものである。そてで抵 抗の少いソフトプレートワックスでは吵下時の舌压の影

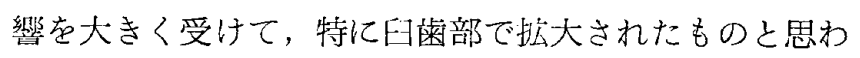
れる. 今後, 筋圧中立率と舌圧およで煩, 口唇圧との関 係, 歯槽頂と筋圧中立帯との関係, 前棵部アーチの形態 などについて検討する予定である. 